\title{
Turning things around? From white fusion stars with Andean flavour
}

\section{to Andean fusion stars with white appeal}

\section{Fiorella Montero-Diaz \\ Keele University}

Popular fusion music in Peru's capital Lima has in recent years grown to a representative genre challenging existing segregation of Limeño society through interethnic and interclass interaction. Focusing on three case studies of Peruvian fusionists performing for the white upper classes, this article documents a shift in racialised notions of Andeanness and marginality among the white upper classes from 1960 to 2014 linking the changes in perception to the political and social context of those years. It examines the trajectories of Miki González - an older white fusion star who hires Andean musicians, La Sarita - an intercultural Andean rock band striving to balance the urban and the Andean, and Magaly Solier - a young Andean campesina ('peasant') actress and singer who hires white musicians. These case studies demonstrate how fusion music interactions contribute to reshape traditional cultural imaginaries, challenge racism, and project images of empowerment onto 21 st century Andeans.

In 1855 Sebastián Lorente, the Spanish-born Dean of Literature and Languages at Peru's then most influential university, Universidad Mayor de San Marcos, wrote about Andean peasants in Pensamientos sobre el Perú:

\footnotetext{
They are mired in ignorance, they are cowardly, indolent, incapable of recognizing any benefit, they are callous, lazy, thieving, they have no respect for the truth and have no noble feelings, they vegetate in abject poverty and worries, living out drunken days and lewd nights (Lorente 1980 [1855]: 117).
}

A century and a half later, in 2006, Peru voted its first Quechua representatives into Congress: Hilaria Supa and Maria Sumire, ${ }^{1}$ but controversy 
ensued. Other members of congress, especially Dr Martha Hildebrandt, former Speaker of the House (1999-2000) and influential Peruvian linguist, ${ }^{2}$ openly rejected the two members wearing traditional garments and addressing Congress in Quechua. There were constant clashes inside and outside of the chamber, notably following a debate in September 2007 about indigenous languages when Hildebrandt and Sumire confronted each other in front of the press,

... She (Sumire), I don't know what intellectual works she has produced, I have produced around 30 or 40 referenced and translated books, so those are low blows from people who lack both intellectual capacity and university degree... Just imagine, I have been Under Secretary General, not of Peru, but of UNESCO worldwide and she [looking at Sumire]... is going to come here and teach me about education, oh no... each in their place, each in their place... I have sold almost ten thousand copies of $L a$ Lengua Culta [Hildebrandt's best known book]; you have probably not read it (...) [turning back to the cameras] I can talk to my intellectual equals at a conference on linguistics at The Royal Academy of the Spanish Language. I am the only woman in the Academy, but she knows nothing about linguistics (...). They [Sumire and Supa] are quite frankly laughable... (Hildebrandt 2006). ${ }^{3}$

One hundred and fifty two years separate Lorente and Hildebrandt's statements, but not much seems to have changed. Indigenous peoples have gained visibility in Peruvian politics, but are continuously discriminated against and disregarded by the white elites and by politicians, many of whom view indigenous culture as inferior. In the mainstream media and Limeño [Lima residents] middle and upper class imaginary, indigeneity is commonly associated with 'museum piece' identities and lifestyles, idyllic images of hyper-reality (Ramos 1994), poverty, victimisation and is used as a source of racist jokes (Peirano and Sánchez 1984, Ardito 2004). In Lima indigeneity is associated with cultural backwardness and 
marginal economic classes, social interactions are also generally hierarchised: whites rank above mestizos, and mestizos above indigenous-Andeans (Turino 1993, Portocarrero 1993, Mendoza 2000). ${ }^{4}$

These hierarchies and the rejection of Andeans ${ }^{5}$ are reflected in music. For centuries Andean and provincial musical expressions were classed by traditional white upper class Limeños as bad taste and only for the poor. Music taste and music affinities were clearly racialised (c.f. Haynes 2013: 145), negative attitudes towards a particular social group resulted in negative attitudes towards the music associated with that group (c.f. Bryson 2002: 113). The dismissal of traditional and urban Andean music styles has been most broadly examined in studies on chicha (Tucker 2013a: 141, Romero 2007: 31, Bailón 2004: 58-59, Ramos-García 2003: 201, Quispe 2000), a music style that achieved mass popularity among Andean migrants in Lima in the $1980 \mathrm{~s}$.

In 2013 Joshua Tucker reviewed chicha studies in Peru, mostly published in the 1980s, 90s and early 00s, highlighting the multiple academic accounts that positioned the style as an icon of Andean migrants in Lima and of Lima's migrant social transformation. Most accounts hailed the style as a transcendental response to social change, only to be disappointed with its failure to challenge the hegemonic Limeño context and to achieve the predicted sociopolitical vindication (2013a: 159$60)$.

However, during the 1990s provincial performers innovated with hybrid chicha styles, such as a blend of tex-mex, ranchera style, pop and chicha branded as technocumbia (Romero 2007: 36-40). Rossy War, who pioneered this style, took her music to the most exclusive homes in Lima, This sonic subversion of class hierarchy attracted upper class youth to heavily racialised music styles associated with 
Andeanness and paved the way for a gradual upper class rapprochement with chicha, provincial styles, such as cumbia amazónica and cumbia norteña, and more traditional styles like huayno. ${ }^{6}$ In the 2000s, contemporary huayno Ayacuchano artists, like Hermanos Gaitán Castro and William Luna peaked in popularity in Lima performing at concerts drawing tens of thousands (Tucker 2013b). The slow incursion of stigmatized provincial performers (1990s and 2000s) playing genres associated with subalternity (chicha, technocumbia, and huayno), into Lima's music circuits brought these genres to a broad Lima audience, including the upper classes who initially reacted with rejection, but later embraced them. During this period Limeños opened up to a newly cosmopolitan, multicultural version of Peruvianness triggering a proliferation of fused genres and intercultural collaborations.

After 2005 with the rising popularity of Lima fusion music, ${ }^{7}$ Limeño white upper class bands, ${ }^{8}$ such as Bareto and Dengue, Dengue, Dengue, released remixes and tribute albums of chicha and cumbia. They topped the sales charts in Lima and served as a platform for broader discussions on sociocultural, class and ethnic interactions in Peru's capital. Arguably, their success and impact confirm, albeit later and more indirectly than expected, the potential of marginalised music styles, like chicha, to challenge hegemony. This broadening of white upper class music taste was linked to the internal war (1980-2000). In its aftermath some upper class youths no longer viewed 'exclusivity' as a quality, but a limitation to overcome through popular culture (Montero-Diaz 2016). Interclass and interethnic music onstage collaborations proliferated in this context. ${ }^{9}$

Race has frequently featured in the study of subaltern communities and repressed peoples in areas of ethnomusicology like 'black music' and 'indigenous music'. There are also studies on elite appropriations and approaches to popular 
culture (e.g. Vianna 1999, Wade 2000, Moore 1997). However, not much has been written about the popular music consumption patterns of the white upper class in Lima and their underlying motivations, at least not beyond an essentialist association with criollo music or through an interpretative framework of cultural appropriation. Furthermore, not much has been produced about musicians' processes of conviviality and negotiation of difference through intercultural music collaborations.

Issues such as appropriation, exoticisation and representation have received extensive coverage in the literature, for example global appropriation phenomena and cultural theft (Feld 2000b, 1996: 24-26, Stokes 2004: 56-58, Hesmondhalgh 2000, Taylor 2003), anxious and celebratory discourses about World music hybridity (Feld 2000a, Lipsitz 1997, Slobin 1993, Born and Hesmondhalgh 2000), hybridity and cultural mixture and mestizaje (Ritter 2011; Taylor 1997, 2007), "Columbus effect" and paternalistic 'cultural rescues' (Valentin Escobar 2000) and processes of globalization impact on local musics (Ochoa 2003). I am aware of the global market forces at play in local musics, but I argue that such forces do not impact local culture vertically, but rather as an ongoing bilateral process of music glocalisation, cosmopolitanism, musicians 'cannibalisation' of the foreign to make it local.

Based on ethnographic testimonies gathered between 2010 and 2011, and informed by the rich literature on cultural contact, this article explores the impact of music hybridity and intercultural collaboration on gradual shifts in racialised notions of Andeanness, indigeneity and marginality among a sector of the white upper classes from 1960 to 2014 linking the changes in perception to the political and social context of those years. Drawing on ethnography it examines the trajectories of Miki González - an older white fusion star who hires Andean musicians, La Sarita - an intercultural Andean rock band striving to strike a balance between the urban and the Andean, and 
Magaly Solier - a young Andean campesina ('peasant') film star and singer who hires white musicians. These musicians have contributed to shifting social imaginaries of alterity and racialised 'allowed spaces', places perceived by the upper classes as sheltered from difference and poverty-free. ${ }^{10}$ This is an attempt to document a moment in which Lima-based musicians used new languages of multicultural selfhood to understand themselves as more open to equality through intercultural collaborations, able to engage and visibilize horizontal dialogue through music performance and, in some cases, conviviality. A few similar music trends existed before the period discussed in this article (e.g. Yma Sumac exotica in the 1930s and 1940s, Inca foxtrots in Cuzco in 1930s), but the difference between these and the contemporary fusion music scene is the latter's impact on their white upper class audience, the use of music as a lifestyle and political distinction marker among a sector of the young upper classes, the role of intercultural dialogue in the creative process, and the manifestation of a desire for rapprochement with previously marginalized music genres to gain a sense of belonging.

There have always been educated white privileged limeños who resisted the country's historic prejudices. However, the current visibility of these new upper class music taste and cultural ventures translates into a proliferation of intercultural dialogues and public discussion on fusion music, which make Lima's public, including some of the most privileged in the city, more alert to displays of white superiority and racism. In parallel, this cultural transformation has enabled other sections of society to demand a change in upper class social habits. These twin trends are prying open the door to more plural social dialogue and sustainable action.

\section{Miki González: Intercultural curiosity?}


In the late 1960s and early 1970s President Juan Velasco Alvarado, a left-wing army general, enacted a series of nationalist reforms, including prohibiting the use of the term Indian and promoting traditional Andean music in the media. His de facto ban on 'foreign capitalist music genres' (Riveros 2012: 149) forced several young white upper class Limeño musicians to to marry their foreign passions (rock, jazz and blues) with local styles, fusions became a means to avoid completely abandoning foreign influences. This was how upper class Andean fusion group El Polen, often cited as the first band to combine Andean instruments and melodies with rock, was born. Miki González was influenced by El Polen, later befriending its founders brothers Raúl Pereira and Juan Luis Pereira, but in his own work Miki fused jazz, blues and Afro-Peruvian music. ${ }^{11}$

In the mid-1970s, Miki formed the band Los Chonducos, which, along with a second Afro-jazz fusion music project, Oba Meboto, would become one of the first significant opportunities for instrumentalists involved in the Lima jazz scene to rethink their relationship with Peruvian music (Miki González in Olazo 2002: 50-51). Some of these musicians were already occasionally playing for música criolla ${ }^{12}$ interpreters and are now acknowledged as harmonic innovators in Peruvian waltz and Afro-Peruvian music.

While the internal war and the Shining Path's ${ }^{13}$ violence crippled entire Andean provinces in the mid 1980s, Miki moved from jazz to rock with elements of Afro-Peruvian music. He formed a band with upper class rock musicians and invited Filomeno Ballumbrosio, a member of one of the most emblematic families of AfroPeruvian musicians in El Carmen, Chincha, the heartland of Afro-Peruvian culture, to play Afro percussion (c.f. Feldman 2006). During the 1980s, Miki and his rock band played a major role in the rock scene in Lima. His lyrics did not shy away from 
thorny issues: the internal war, corruption, racism, consumerism, drug trafficking, and others. Miki embodied youthful protest and became an emblematic figure, in spite of the internal war and economic turmoil that had plunged the music industry into acute crisis. The social critique expressed in his lyrics sparked controversy, no label was initially willing to record him and radio stations shunned some of his songs for fear of state repression (c.f. Balabarca 2013: 85-85). Still, his music videos often appeared in the media, portraying intercultural and interclass mainstream rock collaborations. It was the first time this type of genre and collaboration came to enjoy mass public acceptance. Miki was born in Spain, but came to Lima at a very young age. Perhaps his initial categorisation as a foreigner, his tall stature, white features and light eyes, and the fact that he was a hippie upper class musician willing to transgress his 'allowed space' facilitated his acceptance in Chincha and the Andes, as well as the dissemination of his political statements.

In the early 1990s, as the war encroached on Lima, Miki consolidated his place in Afro-rock through further collaborations with the Ballumbrosio family. He lived with them in Chincha researching Peruvian Afro roots and getting to know them. He collaborated with Amador Ballumbrosio, one of the Chincha community elders. During this decade, his music videos not only portrayed intercultural collaborations, but some were filmed in Chincha and featured the Ballumbrosio family and other Chincha residents. This meant that the social realities of black AfroPeruvians were disseminated in the Peruvian media along with a message of equality and friendship that transcended 'allowed spaces', skin colour and social class. ${ }^{14}$

The war caused large-scale migration, both internal and external in the 1980s and 90s. The high numbers of Andeans displaced to Lima during those decades who made their homes in the city's peripheries (or conos) was termed desborde popular 
('popular sector spill-over') (Matos Mar 1984). The displacement 'revived centuryold patterns of discrimination and social exclusion of the Andean migrant population on behalf of the elite...' (Dalum Berg 2007: 90). Traditional middle and upper class reactions to the Andean 'cholificación of Lima' (Quijano 1980) intensified racism and segregation in the city. ${ }^{15}$ With the increased presence of internal migrants working in Lima's historic center (in markets and as street vendors), ${ }^{16}$ the upper classes left their traditional areas for new homes in Magdalena, Miraflores, San Isidro, and later in La Molina. But they were rapidly encircled with the accelerate growth of shantytowns and old Lima became surrounded by new peripheral emerging districts. ${ }^{17}$

It was in this tense political context of the mid/late 1990s, that Miki turned his attention to Andean music and collaborated with Andean vernacular singers such as Rosita del Cusco. He would speak Quechua at his concerts and music videos, another novelty in Lima where Quechua was widely perceived as backward and something of which to be ashamed (c.f. García 2005, Flores Galindo 1994, Mendoza 2000, 2008). However, Miki's music videos also presented a very romantic idea of Andeans as speaking only Quechua, wearing traditional costume, dancing through Inca ruins and engaging in rituals like coca leaf divinations (e.g. in the music video to Hoja verde de la coca) ${ }^{18}$ Nevertheless, his music trajectory helped him to legitimise his essentialist portrayals perceived as a white upper class approach to Peruvianness born out of sincere curiosity and interest.

Miki was not the very first Peruvian fusionist, but a local shift in popular urban taste and fusion acceptance occurred with him. Yma Sumac, arguably the first Peruvian fusionist (1950s), was perceived as an Andean diva succeeding in the US and Europe, while Miki was a white European engaging with Peruvian sounds in Lima. Once again, Miki's foreign roots may have made it easier for him to bridge 
Peruvian social divides than for the local-born white upper classes whose background was inexorably intertwined with the knotted fabric of Peruvian class hierarchy.

From 2004 - the internal war officially ended in 2000 - Miki started fusing electronica with Andean tunes pioneering a new genre, which would be further developed by musicians such as Jaime Cuadra, Novalima and Radio Quijada. Miki's image was no longer that of a youthful rebel, by his mid-fifties he was focusing on lounge music aimed at tourists and the white upper classes. These electronic fusions were coopted by the Peruvian Government to set the tone at official events and receptions, and for commercial projects evoking nationalist sentiments. ${ }^{19}$ During this period, when talking about his music and collaborations with Andean musicians, Miki took pride in how 'authentic' he felt they were,

Carlos Enciso who is the specialist in altiplano ${ }^{20}$ music brought Johny Rodriguez (...) I have the privilege of having an authentic guy from the altiplano, you get me? And he adapts and he laughs his ass off. I have a Ballumbrosio, the Ballumbrosios are authentic. (Miki González, interview, July 2008).

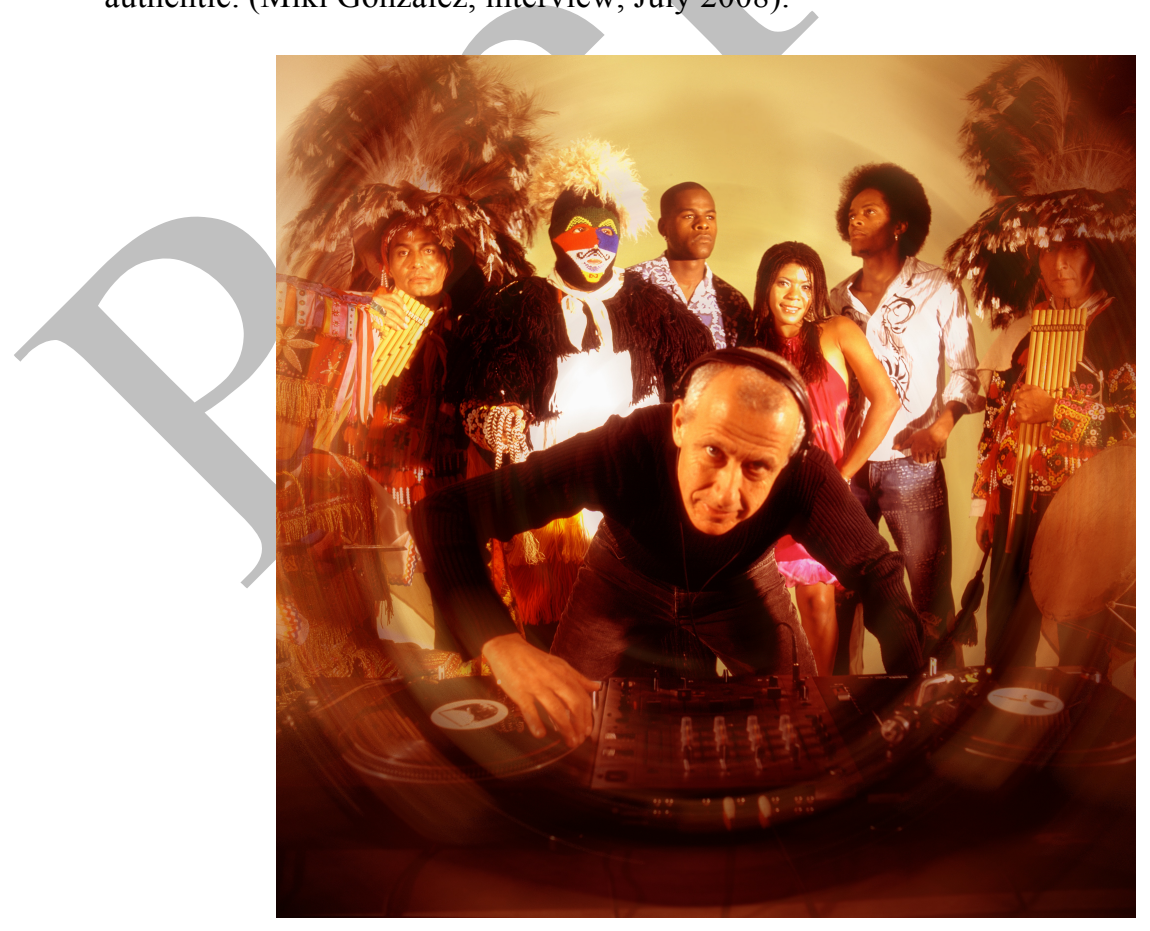

Figure 1: Miki González - Etno Tronics. Source: Miki González. Photographer: Diego Alvarado. Used with permission of Miki González. 
Version post-peer-review, pre editing; do not cite without permission of author

This notion of authenticity was also reflected in some of Miki's early music videos where he portrayed the Andean world as iconic, romantic and mystic. Miki's Andean-electronic fusions made traditional Andean music 'cool' for the upper classes. Peruvian musicologist Chalena Vásquez says:

Well, a friend who worked at the Recoleta [upper-class secondary school in Lima] (...) told me that Miki González' music was a bridge for her, that before showing them a huayno the way it is, she would show them Miki. So they would start to accept, so that they would get to dance traditional music. It was a bridge. And in some way it can fulfil that role. Well, if you want to cross the bridge, because if you don't, you just stay where you are. (Chalena Vásquez, interview, August 2010).

But is this musical 'bridge' just another middle and upper class representation of Andeanness? What role do the Andeans themselves play in this music process? Miki's onstage DJ format (2006) was severely criticised by other fusion performers and audience for his indigenista outtake, Miki seemed to be making music that would not be considered 'traditional' Andean music, but more of a reflection of how city dwellers imagined the Andean (see Montero-Diaz 2017). In a way, he was speaking for the Andean, but not letting the Andean speak for himself. Furthermore, Miki takes sole credit as the creator of his fusions, even though the recording process is a collaboration. Miki's creative process involves recording a musician in the studio playing the 'authentic' melodies and then reconfiguring everything, so the Andean musician has to relearn the traditional song in a new electronic configuration before the performance. Dimitri Manga, researcher and one of Miki's music collaborators says:

In Miki's music, even in the fusion bands, the instruments often add a touch of colour or support, (...) their entire aesthetics, adapt to the framework and with this to the 
Version post- peer-review, pre editing; do not cite without permission of author

sound context of the whole band, so we are not on an equal footing in some way, so we will always paint, add colour or support in some way, but we will not play a lead role (Dimitri Manga, interview, July 2010).

From 2005 onwards, fusion music and fusion gastronomy were widely used in Lima to express a modern identity based on traditional elements of culture and as a means to boost self-esteem in the aftermath of war. A few years later, Miki's ElectroAndean fusions began to attract widespread condemnation; he was accused of appropriating and de-contextualising traditional Andean music for the sake of his own financial gain. The criticism mostly came from Limeños of Andean background and opened up discussions of white privilege. Even Miki's Spanish nationality was brought up in debates about his sampling methods and onstage collaborations. Other fusion musicians and parts of the upper class fusion audience also disliked his onstage DJ format, with him in the centre, elevated behind a turntable, and his musicians playing and dancing below him. To some, he appeared to be replicating the figure of 'the white master with his Indian puppets'. ${ }^{21}$ His phenotype and origin, which once facilitated access to restricted spaces of intercultural interaction, started to play against him in the 2000 s.

Each decade of Miki's innovation drew distinct responses from the Limeño public, as they reacted to different historical moments and to the changing perception of the growing number of Andeans in Lima. In the 1980s, punk and rock Afro fusions crystallised protest against terrorism and segregation. In the 1990s Afro/white dialogues, and later Andean/reggae and ska, contributed to promoting inter-ethnic contact and trust, while the internal war was generating the exact opposite. In the 2000s, electronic fusions were used by the Peruvian Government (post Fujimori), and later the official country brand Marca Perú, ${ }^{22}$ to build a modern image of an 
Version post- peer-review, pre editing; do not cite without permission of author

integrated country. The internal war was over and the Government wanted to foster optimism and national pride among Peruvians. From 2008 onwards Miki was heavily criticised for replicating hegemonic models in music performance, essentialising Andeanness and using possessive language when referring to the musicians in his band. Though Miki has not changed his discourse, expression and ideas about his collaborations, it seems his audiences have, including the white upper classes, previously mostly oblivious to problems of representation, a newfound awareness of power relations in music making. Lima's public has become more alert to displays of white superiority, and Miki is perhaps one of the main triggers of social commentary.

Miki's trajectory as a fusion pioneer highlights shifting historical attitudes to fusion and to racial interactions and relations through music making. It also illustrates the ambiguity of the perceived meaning of fusion music as inclusion or a marker of social inequality and cultural difference, as it is reinterpreted by listeners responding to and shaping historical and socio-political contexts. However, changing perceptions of Miki's music cannot be solely attributed to shifting attitudes shaped by politics; the music scene itself and more frequent intercultural collaborations have contributed to the creation of and demand for more equal and horizontal musical dialogues. Even music interactions forged with an ambiguous array of appropriations can contribute to individual and collective reflection by generating curiosity and discussions among musicians and the public about power, ethics, impact and agency.

\section{La Sarita: striking a balance between the urban and the Andean}

In 1990, the start of the second decade of war, Alberto Fujimori was elected president. His regime lasted ten years (1990-2000) and ended abruptly when he fled to Japan and resigned from the presidency by fax. In office he steered Peru towards 
neoliberalism through tough economic reforms and privatizations (Weyland 2007). In 1992 he executed what was termed el autogolpe ('self-coup') by dissolving Congress, suspending the constitution and purging critics from the ranks of the judiciary (see Madrid 2012, Mauceri 1995). Corruption was subsequently institutionalized via the head of the intelligence service - Vladimiro Montesinos - who had most of Congress, the media and many public figures on his extra official payroll. Fujimori is now serving time in Peru for abuse of authority, corruption and crimes against humanity.

In the political setting of the 1990s, La Sarita embodied young middle and working class protest against President Alberto Fujimori. La Sarita would gradually diversify, growing into an eleven-piece band over the 2000s with members from the Amazon, the Andes and different areas of Lima from very different socio-economic backgrounds. In the postwar context, La Sarita openly promoted social inclusion, fought discrimination and racism and celebrated diversity, positioning itself as one of the most influential bands in the fusion circuit. $^{23}$

With the album Más Poder ('More Power' 1999), La Sarita started fusing Andean music, especially chicha, with heavy rock. Later, in Danza la Raza ('Our Race Dances' 2003), the group combined rock sounds with the traditional Andean Danza de Tijeras ('Scissors dance'). For this album, La Sarita invited Marino Marcacuzco, a violinist from Ayacucho, 'Challwa' ('Fish', Julio Salaverry), a danzaq ${ }^{24}$ playing the scissors and the Andean harpist 'Tukucha de Chiwiri' ('Little Owl of Chiwiri', Hector Rojas Flores). Like Miki, La Sarita in the late 1990s initially wanted 'totally rural musicians, [for] more purity' (Pérez as quoted in Rozas 2007: 79), but later focused on the intercultural connection that came with shared experience,

...we realised that the music had to be a result of shared experience... of understanding between people. Realising that music is a means, not the end. The end 
Version post-peer-review, pre editing; do not cite without permission of author

is all of us. Imagine, the first song we made with the scissors' dance was after a year. Actually nothing might have come off it, but thank God things started to flow, after a year of sharing a song emerged and it's a half-finished song, it's Danza la Raza (Julio Pérez, interview, July 2010).

An unplugged video of 'Danza la Raza' starts with Marino and Tukucha playing a traditional scissors dance tune followed by Martin Choy on the electro acoustic guitar and Dante Oliveros on snare drum. One minute in, the track mutes to a soft punk with some scissors dance rhythm and breaks, here Marino and Tukucha follow the urban musicians and musically 'move to the background'. The more traditional tune returns around the third minute to introduce Challwa's scissors dance, the rock section of the band pauses while the dance takes place, after a minute Challwa stops dancing and Julio Pérez recites some words in Quechua and the soft punk resumes. The song feels sectioned; the Andean tunes do not mix fluidly with the rock band. Onstage, the Andean musicians are on one side of the stage close to Martin Choy on his guitar, who is counting and leading so they know exactly when to come in and when to stop. The Andean musicians and the danzaq appear insecure in trying to follow the other musicians. As for the dancing, Challwa performs traditional steps while looking rather bewildered with the punk rhythm. ${ }^{25}$ Maybe this is why Julio now calls this a 'half-finished song' (ibid. July 2010). For their middle and upper class public, it was a nice way to 'colour' the show; it was innovative to have Andean traditional musicians onstage. However, as one member of the audience said, 'they used to be quite ornamental' (Mariafé 28, La Noche, 2011).

La Sarita's yearning for a more articulated Peru fuelled their conscious effort to get to know each other better by spending time together and exploring each other's environments. Finally, in 2009, after six years of creative silence, they launched the 
album 'Mamacha Simona' featuring a fusion of traditional Andean music with rock, punk, and cumbias. On this album it is very difficult to separate the different genres in the mix, which is fluid and compact. As an upper class fan of La Sarita puts it: 'It is a completely new thing, truly a new rock that sounds like a new Peru' (Maria Fernanda 26, La Noche, 2011). Renato, the member of the group from the wealthiest background, often referred to by the other members as el pituco de La Sarita ('the posh band member') says:

...it was difficult [the intercultural interaction]... musically and socially. I mean there was a certain caution, distance. Both on their side [provincial musicians and dancers] and on our side [Limeño musicians]. Because you might have the best of intentions, but sometimes your own narrow focus, which you get from school, you get from society, makes you like that, right? (Renato Briones, interview, August 2010).

The process was protracted; the band decided to fuse themselves in order to fuse their music, which affected them in many ways. Socially, as Renato said, they had to overcome internalised stereotypes and prejudices to be able to see each other as equals in order to produce the music they wanted to make. This also involved learning and valuing each other's cosmology, religion, language, background, life stories, etc. Each musician had plenty of stories about their mutual discovery and they did not hide their emotions while retelling them to me,

... on the way from Zurich to Geneva... the sun was rising and Marino woke up, he was next to me. (...) He started saying: 'that's barley' and I start looking 'Really?' I say, 'yes, and that's wheat' 'really?' 'yes, and that's potatoes'. (...) And that will be ready for harvesting by then. And, I don't know, he started teaching me things (...) he was imparting knowledge to me, which to me really had the feel of wisdom, I started appreciating him much more (...). I thought it was fabulous. That day I... I feel like I really bonded with Marino (Renato Briones, interview, August 2010). 


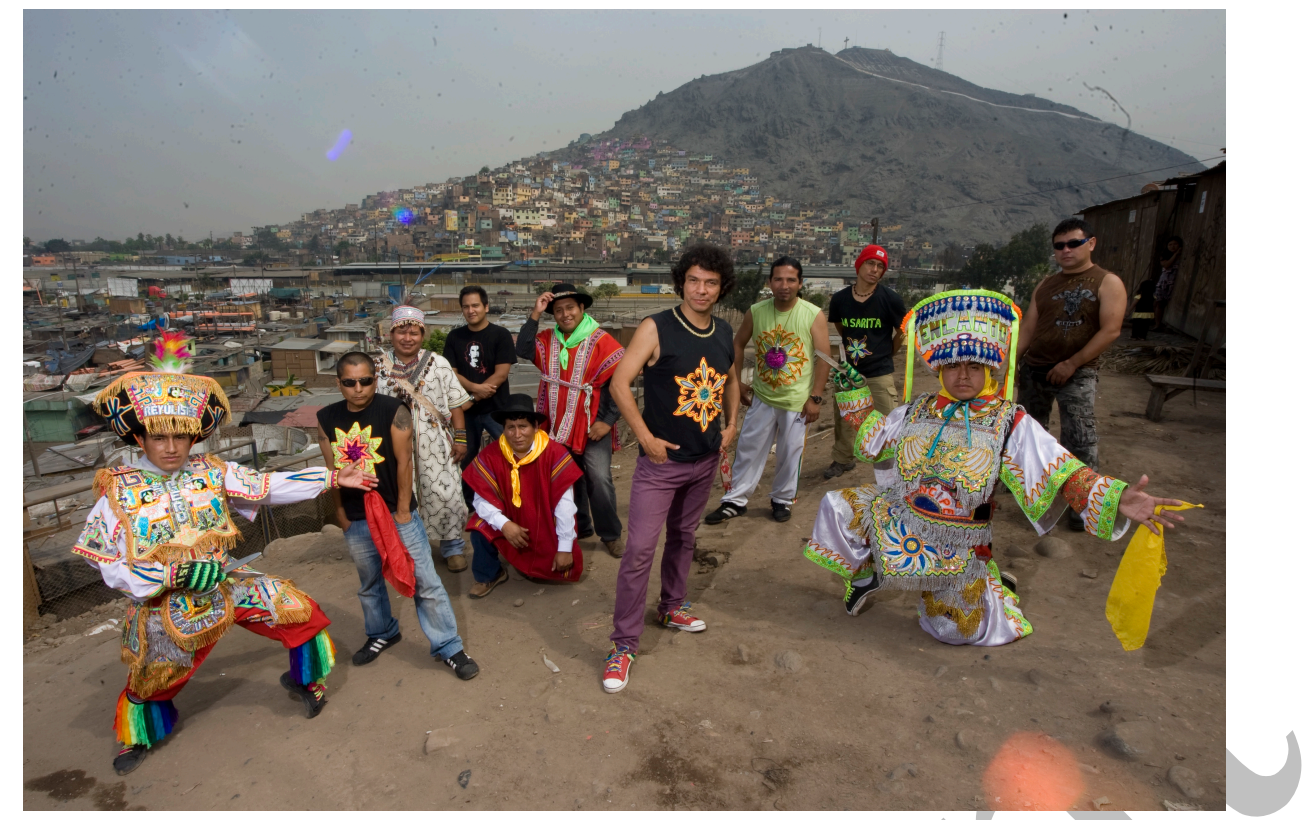

Figure 2: La Sarita and all its members. Source: Julio Pérez (centre of the picture). Photographer Luis Choy-Yin. Used with the permission of Julio Pérez.

When Marino first joined the group, the Andean musicians and dancers had to follow the rock section of the band, but, in time, the rock section began to follow them, giving them more agency in the creative process and onstage presence,

...now we put out the Andean music and they adapt to us and they add the beat (...)

For the album 'Mamacha Simona', Julio always came to my place, almost every day.

We worked for months to compose everything. All the compositions in Quechua are mine, everything I'm singing (...) On the CD [credits] they have included me, yes, as a composer (Marino Marcacuzco, interview, September 2010).

In concerts Marino Marcacuzco would take centre-stage, in contrast with Miki's DJ-centred onstage format. His violin movements were decisive and he danced to rock while playing Andean tunes. He would sing in Quechua while the audience chanted: 'Marino, Marino, grande Marino'. Marino's creative work is recognised by La Sarita. From the production of Mamacha Simona onwards he has been considered part of the core group, and paid the same as the rock section. 
La Sarita started as an underground rock band, it became a fusion band indexing Andeanness and later emerged as a fusion ensemble based on horizontal creative dialogue. Striking a balance between the urban and the rural, the Andean and the Limeño, the wealthy and the poor was difficult, but La Sarita made a conscious effort. For Renato, the new album ('Identidad' 2012) once again reshuffles the compositional creative process; they are not 'only' playing around Marino and his violin, now the violin and harp are playing non-traditional music, they are exploring new sonorities all together from their different traditions and sounds.

\footnotetext{
... we're working on a song, there is a solo sounding like bluegrass, music from New Orleans, right? Marino came and he joined because we had to rehearse a song, which we have to play with him and, well, let's hear it 'Marino solo' and he started playing a solo and, well, it sounded like music from the States, like music from Alabama and I was dumbfounded by how well he played, he was a virtuoso, but he was playing because there was a bond. (...) I swear that out of the 5 songs we have so far not one is traditional, and that's what's interesting, that the violin and harp are playing songs that aren't traditional (Renato Briones, interview, March 2011).
}

La Sarita's intercultural process is an example of how collaborations between Limeños and Andeans can change from indexing Andeanness, through intercultural dialogue playing the 'other's' tradition together, and beyond to deploying these intercultural tools and different music languages to approach new music unfettered as equals. Martin Stokes (1994: 10) has noted that music does not unite diverse people, it makes them approach each other, but with tensions and discomfort, Jonathan Ritter observes that hybrid music is allied with dominant discourses of mestizaje or even whitening, and negates discrimination against those who do not fit the mestizo nationalist frame (2011: 573). However, La Sarita is not following this mestizo trend. Their music process does not transcend racialization, but rather allows difference to 
become audible. Their work stages the identities in contact, renders audible this process and demands that these components should come into contact, without dissolving the essential elements. La Sarita offers the white upper class audiences a musical demonstration of what can be achieved, of the possible, and in this way, the band politically resensitises them.

I liked La Sarita for its staging, the political aspect wasn't very important to me, the band in itself entertained me. But as I started liking the music more and more, the message got into my head, it made me think. My friends who were fans of La Sarita discussed other things, not just the staging, and that's when it clicked; there was something deeper which my superficial side refused to acknowledge. I feel that the music entered first and the message afterwards... (male, 26) ${ }^{26}$

The movement from Miki, who seemed curious about an 'other', to La Sarita denotes a shift towards a desire for a more balanced intercultural musical dialogue, where members, through musicking, learn from each other and build different relationships, self-recreating themselves. The learning experience is mutual and this is recognised by all of La Sarita's members. The transition from Miki to La Sarita is, of course, not linear; it is a convoluted, circular and overlapping process of dialogue, experience and musician/audience feedback.

\section{Magaly Solier: Andean fusion star with white appeal}

Following the internal war and Fujimori's regime, historical racial tensions were exploited by populist politicians, such as President Alejandro Toledo (20012006), who during his 2001 presidential campaign acted as the personification of Inca Pachacutec. ${ }^{27}$ During his term he also played on the Inkarri legend as the personification of a returned inca, ${ }^{28}$ a strategy of indigenous vindication (see also 
Greene 2009: 140, García 2005: 170). In the run up to the following presidential elections in 2006, the then presidential candidate Ollanta Humala campaigned on a platform of governing for the bronze skin, threatening the blanquitos ('little white people') and foreigners with expulsion from the 'new country'. Ollanta Humala lost in 2006 to his main rival Alan García who, ${ }^{29}$ during his mandate, made repeated discriminative remarks about native and indigenous communities and sanctioned a series of indigenous and human rights violations (e.g. Bagua massacre in 2009). In early 2011 President Alan Garcia referred to Andean religiosity in a discussion about mining concessions with these words:
... we must defeat absurd pantheist ideologies, which believe that the walls are gods
and the air is god. Returning to these primitive formulae of religiosity where people say 'don't touch that mountain, because it is an $\mathrm{Apu}$ [spirit of the mountain] and it is filled with the ancient spirit and I don't know what'. Well, if it comes to that then let's not do anything, not mining... (...) we need more education (...) they shouldn't be saying that the soul of the ancestors is in a mountain, the soul of the ancestors is probably in heaven, it's not there..$^{30}$

Magaly Solier, a young self-identified campesina ('indigenous peasant') Andean actress and singer from the Andean region most affected by the internal violence Huanta - Ayacucho, made her musical debut in 2009, the year of the Bagua massacre, during President Alan García's regime. She was already a familiar figure as the star of two major Peruvian movies directed by white upper class filmmaker Claudia Llosa: 'Madeinusa' (2006) and 'The Milk of Sorrow' (2009). In 2009 Magaly released her first album, 'Warmi', produced as an aural-movie (album with a plot and characters) where she sings the emotional journey of a cast of women from Ayacucho after the internal war. Eight out of the eleven songs on the album are in Quechua. 
Following the release, Magaly regularly sang at upper class venues, such as El Cocodrilo Verde and La Noche, usually accompanied by arranger Cali Flores and fusion band Kenyara. Kenyara's members come from very diverse musical backgrounds including western art music, Ayacuchan vernacular music, jazz and música criolla; and also from different social and ethnic backgrounds.

Rather than reproducing typical images of the Andean indigenous campesina in folklorised clothing singing solely 'indigenous music', in order to build up cultural capital, Magaly Solier presents herself as a modern, cosmopolitan Andean woman, capable of speaking Quechua while representing Peru on a global stage. This approach enables her to portray her Andeanness horizontally, destabilising the habitual and expected unequal interaction between traditional Limeños and Andeans.

Several fusion musicians and members of the audience I interviewed during fieldwork told me that other people go to see Magaly because they want to see the actress or the "cholita' 31 sing at an upper class venue. Many musicians did not believe she really knew what she was doing and described her as an industry constructed phenomenon. I encountered a widespread lack of faith in Magaly as an independent artist. Her auto-identification as an indigenous peasant made it difficult for some to believe that she could decide for herself. The same scepticism sparked discussions of her agency as an actress directed by the Peruvian white upper class film director Claudia Llosa. White/indigenous dichotomies immediately conjure up the spectres of ethnic antagonism and exploitation, even when interaction may be perfectly harmonious. However, it was revealing to attend Magaly's sound check at La Noche de Barranco in August 2010. I wanted to observe her relationship with the musicians, the scene and the audience. I found that in addition to commanding control over her music and the stage, she possessed the technical knowledge to request specific sound 
effects during the rehearsal. She asked her sound engineer, Juan Carlos Estremadoyro, to apply delay to cover gaps in sound resulting from the location's acoustics and for one song she said: 'engineer...could you put another voice on top, so that it comes out as two voices?' Juan Carlos replied that they did not have the hardware, but Magaly came up with a quick fix: 'well, then record me right now and put it on when I sing'. She might not have used the technical word 'vocal harmoniser', as some urban musicians would, but she knew which sonority she wanted and how to achieve it. Juan Carlos immediately recorded her.

Magaly was aware of her musicians' versatility and virtuosity, but she also knew her music was a challenge, especially for western art musicians whose aesthetic aim usually entails achieving a clear individual sound. For violinist Maria Elena Pacheco,

I don't make a very Andean colour [on my violin], but I do try to give it what I think might be close to the Andean. That can be playing a bit closer to the bridge, it gives it a bit of a, let's say, dirty touch and with a lot of force... too much, almost roughly, playing roughly... (Maria Elena Pacheco, interview, September 2010).

Maria Elena Pacheco also sang backing vocals for Magaly. For the song Ripu Ripusajami, Maria Elena had to sing niptiquim ('you said') after each of Magaly's phrases. ${ }^{32}$ During the rehearsal, Magaly was not satisfied with Maria Elena's singing, so she approached her and said: "you have to cover your mouth and tighten your throat, your singing is too clear, you are not giving it your all'. Maria Elena looked nervous and incredulous, as if she did not know whether Magaly was joking. She was not; she was looking for a specific sonority and timbre that Maria Elena was not producing. Her singing was 'too clear' as in too clean or pure, too much like Western art music perhaps. Maria Elena laughed nervously and did not cover her mouth, but 
tried to make her voice more nasal, Magaly did not comment further. Her dialogue with the band, the sound engineer, the production and technical team was friendly and horizontal, though she was adamant about getting a 'more Andean sound', not only from herself, but also her musicians. I write a 'more Andean sound', because her fusion style does not have a traditional Andean aesthetic (high octaves, nasal texture or accentuation). The music is already fused and stylised, but Magaly explores different vocal sonorities onstage, some of which closely resemble traditional indigenous or urban Andean styles.

For Magaly the Andean sound was not merely a matter of aesthetics, but representation. A polished Western performance does not accurately reflect the sonic characteristics and preferences of Andean collective music participation (c.f. Turino 1989, Stobart 2006: 193), something Maria Elena did not understand as a desired distinct aesthetic value. For Magaly, Maria Elena was singing too clear, she was 'not giving it [her] all', which demonstrate the dichotomy between the Andean conceptions of timbre, theorised by Henry Stobart as: q'iwa ('thin clear sounds, not aesthetically pleasing and perceived as withholding potential energies'), and tara ('strong, vibrant sounds, full of energy') (Stobart 2013: 112). Maria Elena's characterisation of Andean sounds as 'rough' demonstrate a lack of understanding of Andean aesthetic values. Yet, even though there was no direct communication about contradicting aesthetic values, this experienced was described by Maria Elena and Magaly as a useful interaction bringing together different aesthetic worlds.

During the evening's concert, Magaly was in control of the band and the audience. She sang huaynos and pumpines ${ }^{33}$ with heavy metal gestures and pauses. That night Kenyara was 'her' band and they played her compositions the way she wanted, and in the language she wanted. 
Version post-peer-review, pre editing; do not cite without permission of author

When I started working with maestro Cali, when he asked me things I would say 'Jeez why am I not working with someone who knows Quechua and stops asking', because I didn't like talking or explaining, so it helped me a great deal to explain to him, to tell him in words that I want a cut here, that it make you feel this, that it make you feel that, until he started understanding a bit of Quechua and I would laugh... (Magaly Solier, interview, August 2010).

This illustrates Magaly's creative interaction with Cali and her pride in bilingualism, which the members of Kenyara, regardless of education and class, cannot match. During the concert, she did not hide her Quechua accent, as some others would when performing for a whiter audience.

I love my land, love my traditions and try to share everything I know, everything I have learned so far. I have no reason to close up or be ashamed of what I do (Magaly Solier, interview, August 2010).

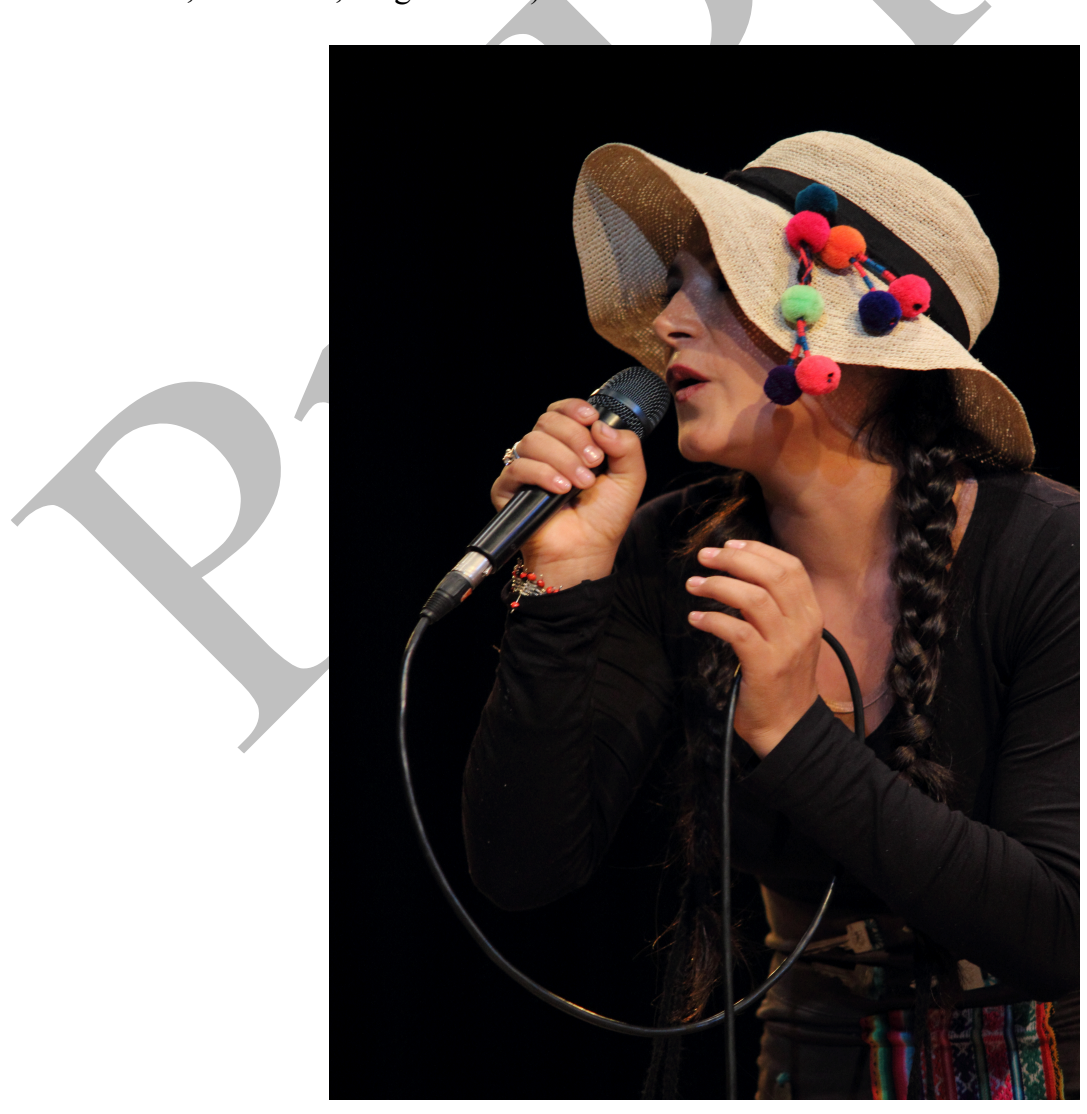

Figure 3: Magaly Solier. Source: Cali Flores. Used with permission of Magaly Solier and Cali Flores. 
Magaly would also joke with the audience about her musicians' 'lack of musical ability', even though they are highly regarded in their own genres: 'Cali maestro, you don't know how to count', 'my musicians don't know how to play this song, so I can't sing it for you now' (Magaly Solier, concert at La Noche, August 2010). These jibes playfully mirror existing discourses about Andean musicians' supposed lack of musical ability when they find Western art music challenging or are unfamiliar with notation and music metric. In this case, the urban Limeño musicians were the ones 'incapable' of playing unfamiliar music aesthetics.

\section{Conclusion: Turning things around?}

It should not be inferred from these examples that indigenous agency in music has changed radically or that indigenous musicians now commonly lead mainstream bands in Peru. Nonetheless, intercultural music projects, and particularly Andean musical presence in sounds and onstage performance at upper class venues, have slowly grown since the 1970 s. This has brought more visibility to some Andean musicians who are now better placed to project their own voice and aesthetics on the fusion scene. Furthermore, this Andean presence, along with more frequent intercultural and interethnic projects and onstage interaction, challenge a generalised genre racialisation, opening the doors to new explorations in aesthetics, shared experience and political discourse mediated by music.

The change in the music scene is intertwined with Lima's socio-economic and political context, which frames and feeds into this space for creation, reflection and discussion among musicians and audiences. In turn, the music scene shapes the sociopolitical environment, as the audiences receive a music message, and perceive the 
music as an opportunity to reflect on their own personal identities, political stances and ideology. The observed trends may take different turns, but charting these processes ethnographically can offer valuable insights into audience reflections and critique of music projects previously accepted as the mainstream norm.

The three fusionist case studies selected illustrate different generations ${ }^{34}$ and modes of interaction. Viewed in context and succession their music and audience reactions to it indicate that the previously accepted and promoted folklorisation of Andean music, where Andeanness was an ornament and an urban representation of an imagined authenticity, is slowly losing out to projections of a challenging more real, modern and equal Andean identity. The shift from Miki González’ music to La Sarita and Magaly Solier is a journey from white fusion stars with Andean flavour ('colour') to Andean fusion stars with white appeal; a music challenge to the segregation of space and genres.

Although there is more evident Andean agency in upper class urban popular music than before, this is an on-going process rather than a culmination. For example, Miki seems to have more authority over the Andean aesthetics he wants from the Andean musicians than Magaly has over her urban musicians. In La Sarita, Marino is a core member of the group, yet Maria Elena was their guest-recording violinist for the album 'Mamacha Simona' (2009). Finally, it can also be argued that the Andeans in these three examples achieved their visibility through bands or contexts where urban/white musicians, producers or movie directors, in the case of Magaly, gave them a 'chance to shine'. Is that full agency? Perhaps not, but this process of Andean self-representation and agency through mainstream popular fusion music is a rapid flux, which is contributing to turning imaginaries around and reconstructing the idea of the indigenous Andean as a modern and competent individual, rather than a 
backward 'authentic' museum piece. If chicha launched a build-up to a degree of social vindication and recognition for urban/Andean aesthetics, cosmologies and community music participation, triggering social commentary and reflection more than thirty years after its heyday in the 1980s; there may yet be grounds for optimism about the transformational potential of fusion music. The door looks open. Fusion music reflects and feeds on-going change in general social context, commentary and imaginaries, illustrating the potential of popular music to generate broad public debates on the fraught interracial, interethnic and interclass interrelations in Peru. Recognition can be the first step to equality.

\footnotetext{
${ }^{1}$ In 2001 Peru elected the Aymara woman Paulina Arpasi as its first indigenous member of Congress during Alejandro Toledo's presidency.

${ }^{2}$ As a linguist, Hildebrandt was a professor of the Universidad Mayor de San Marcos, Director of the Institute of Culture (INC), and Perpetual Secretary of Peruvian Academy of the Spanish Language. She wrote numerous books on linguistics and was quoted and represented in Peruvian media as a mujer culta ('cultivated woman').

${ }^{3}$ For more on this debate: http://peru21.pe/noticia/13893/hildebrandt-sumire-discuten-lenguasaborigenes To watch a recording of the incident as reported on national news: http://www.youtube.com/watch?v=8ahn-tidVwU (Last visited 12/03/2015).

${ }^{4}$ For more on imaginaries of Andean indigeneity see Montero-Diaz 2017.

${ }^{5}$ This term is an agglutinating racialised category used in Lima to describe people born in Andean provinces who live in the Andes or in Lima, and people born in Lima who have Andean ethnic background, phenotype and cultural traits (Andean mestizos). The white upper classes also use the term 'Andean' to reference their imagined idea of indigeneity.

${ }^{6}$ It can be argued that technocumbia of Amazonian origin represented a non-Andean tropical music genre. However, the white upper class collaborators interviewed did not associated this genre with the Amazon, but rather the Andes and particularly with chicha.

${ }^{7}$ Hybrids between what is perceived by the upper classes as traditional music and any foreign genre (e.g. electro-chicha, huayno-rock, afro-jazz).

${ }^{8}$ For more information on methodological considerations in the study of the Lima's white upper classes see Montero-Diaz 2016: 194-5.

${ }^{9}$ For more information about fusion music's role in post-war Lima see Montero-Diaz 2016.

${ }^{10}$ For many Limeños, Lima tends to be restricted to the spaces where they are comfortable among peers. Many seek distance from people they imagine as different ethnically, socially or culturally, creating very real class and race distance and avoidance.

${ }^{11}$ Richie Zellon was also active on the fusion music scene at this time. Some consider him the pioneer of instrumental afro-jazz.

${ }^{12}$ Coastal expression of the musical blending of Spanish and Afro populations. The instruments used also indicate this blend; Spanish guitar sounds with the cajón or spoons as percussive accompaniment. This genre is associated with the Peruvian upper classes as the Spanish elements dominate.

${ }^{13}$ The Shining Path was a maoist terrorist group whose stated aim was to replace bourgeois democracy with a new democracy. It claimed to fight elitist power to empower the campesinos ('indigenous peasants'). However, it committed numerous atrocities against campesinos, soldiers, trade unionists, and others. The violence lasted almost twenty years claiming over 70,000 lives and traumatising the entire country. The Andean region Ayacucho was the most affected.

${ }^{14}$ See video featuring Amador Ballumbrosio (1990s):

http://www.youtube.com/watch? $v=I J 8 c L J b w m H 0 \&$ feature=related (Last accessed 27/10/15).
} 


\footnotetext{
${ }^{15}$ Historically a derogatory term used for indigenous people or mestizos with indigenous cultural traits and phenotype, who speak indigenous languages or practice Andean cultural traditions (even already fused ones, such as chicha music). Typical cholo traits are devalued (Portocarrero 1993). However, over the last decade the concept of mestizaje has started to change from a whitening assimilationist national project to a search for a choledad perdida ('lost choloness'). Choledad represents a nonassimilative mestizaje; a fusion of cultural traits between the Andes and the Coast, which creates a different, more vindicative cholo identity.

${ }^{16}$ The areas adjacent to Lima's Central Plaza flanked by the Presidential Palace and Cathedral.

${ }^{17}$ After migrating to Lima, some displaced Andean families would group and organise invasiones ('land invasions') claiming unused land in the periphery of the city to build new homes (more in Burt 2007, Dosh and Lerager 2010).

${ }^{18}$ For more information see Montero-Diaz 2017: 79-82.

19 Peruvian Cuzqueña beer commercial: http://www.youtube.com/watch?v=NhqNBtCfjR0 (Last accessed 27/10/15).

${ }^{20}$ High plateau in South America comprising parts of Southern Peru, Western Bolivia and Northern Chile and Argentina.

${ }^{21}$ Quote by a mestizo audience member - Barranco Plaza, 2010.

${ }^{22}$ Marca Perú, created by PromPerú - Comisión de Promoción del Perú para la Exportación y el

Turismo ('Peruvian Export and Tourism Promotion Commission'), part of Mincetur (Peruvian Tourism and External Affairs Ministry), is a country brand that seeks to promote local and international tourism by highlighting Peruvian cultural icons in history, gastronomy, sports and music. Marca Perú website: http://www.peru.info/languages/spanish-n.html (Last accessed 21/09/15).

${ }^{23}$ La Sarita's website: http://www.lasaritaperu.com/labanda.html (Last accessed 20/10/15).

${ }^{24}$ For more information on the danza de Tijeras, see Montero-Diaz 2011: 1-18).

25 'Danza la raza unplugged': http://www.youtube.com/watch? $\mathrm{v}=\mathrm{g} 2 \mathrm{Am} 1 \mathrm{LAI} 1 \mathrm{qo}$ (Last accessed 20/10/15).

${ }^{26}$ Quote from an anonymised focus group on the internal war's influence on white upper class audiences.

${ }^{27}$ Pachacutec was the ninth Great Inca (1438-1471/1472). Ruler of the Kingdom of Cusco, which he transformed into the Inca Empire Tawantinsuyu.

${ }^{28}$ According to the Inkarri legend when the Spanish tortured and killed Inca Atahualpa (the last emperor of the Incas), Atahualpa vowed to return to seek revenge. And though the conquerors buried his dismembered body in different parts of Peru, he will rise one day to reclaim his kingdom and then the Andean race will prevail over the whites (Flores Galindo 1994).

${ }^{29}$ Ollanta Humala would later become President (2011-2016).

${ }^{30} \mathrm{https}: / /$ www.youtube.com/watch?v=2Vf4WfS5t08 Uploaded 17/06/11. (Last accessed 19/08/15).

${ }^{31}$ These opinions hinted at the presumed exoticism that Magaly with her Andean ethnicity, background, phenotype and cultural traits could be perceived to bring to the non-alternative upper class.

${ }^{32}$ Magaly Solier's own orthographic representation.

${ }^{33}$ Genre of carnival music from Ayacucho - Peru. In the 1990s composers of this music style commemorate the losses of the internal war and use it to discuss other relevant national and international political issues of the time (Ritter 2007: 183-185).

${ }^{34}$ Miki González was born in 1952, La Sarita's average age was 40 (in 2014) and Magaly Solier was born in 1986.
} 
Version post-peer-review, pre editing; do not cite without permission of author

\section{Acknowledgements}

I wish to acknowledge the generosity and trust of Miki González, Magaly Solier and

La Sarita, and their white upper class audiences. Without their open and frank collaboration this research would not have been possible. I would also like to thank Dr Henry Stobart and Prof. Geoffrey Baker for their time and the comments on drafts. Needless to say, any shortcomings are, of course, entirely my own responsibility.

\section{References and bibliography}

Ardito Vega, W. 2004. 'La Paisana Jacinta: Humor y Racismo', in Ideelemail № 390 (Lima, Instituto de Defensa Legal).

Bailón, J. 2004. 'La chicha no muere ni se destruye, solo se transforma. Vida, historia y milagros de la cumbia peruana', in Iconos 18 (Ecuador, FLACSO), pp. 53-62.

Balabarca, L. 2013. 'Social Denunciation of the Politics of Fear: Rock Music through the Eighties in Argentina, Chile, and Peru', in Song and Social Change in Latin America, ed. L. Shaw, (Lanham, Md Lexington Books), pp. $77-90$.

Born Georgina and David Hesmondhalgh, eds. 2000. Western Music and its Others: Difference, Representation and Appropriation in Music, (Berkeley: University of California Press).

Bryson, B. 2002. 'Symbolic Exclusion and Musical Dislikes', in Cultural Sociology, ed. L. Spillman, (Oxford, Blackwell Publishing), pp. 108-119.

Burt, Jo-Marie. 2007. Political violence and the authoritarian state in Peru: silencing civil society, (New York, Palgrave McMillan).

Dalum Berg, U. 2007. 'Mediating self and community: Membership, sociality, 
Version post- peer-review, pre editing; do not cite without permission of author

and communicative practices in Peruvian migration to the United States' Ph.D diss., New York University.

Dosh, Paul and Lerager, James. 2010. Demanding the Land: Urban Popular Movements in Peru and Ecuador, 1990-2005, (University Park, Pennsylvania State University Press).

Feld, Steven. 1996. 'Pygmy POP. A Genealogy of Schizophonic Mimesis'. In Yearbook for Traditional Music, 28 (1996): 1-35. 2000a. 'A Sweet Lullaby for World Music', in Public Culture, 12 (1): 145171.

- 2000b. 'The poetics and politics of Pygmy Pop.' In Western Music and its Others: Difference, Representation and Appropriation in Music, eds. G. Born and D. Hesmondhalgh, Berkeley, University of California Press, pp. 280-304. Feldman, H. 2006. Black Rhythms of Peru: Reviving African Musical Heritage in the Black Pacific (Middletown, Wesleyan University Press).

Flores Galindo, A. 1994 [1986]. Buscando un Inca. Identidad y Utopía en los Andes (Lima, Horizonte).

Garcia, Ma. E. 2005. Making indigenous citizens (Standford, CA, Standford University Press).

Greene, S. 2009. Customizing Indigeneity (Standford, CA, Standford University Press).

Haynes, J. 2013. Music, Difference and the Residue of Race (London, Routledge). Hesmondhalgh, David. 2000. 'International times: fusions, exoticisms and antiracism in electronic dance music', in Western Music and its Others: Difference, Representation and Appropriation in Music, ed. G. Born and D. Hesmondhalgh, (Berkeley: University of California Press), pp 280-304. 
Version post- peer-review, pre editing; do not cite without permission of author

Lipsitz, George. 1997 [1994]. Dangerous Crossroads. Popular Music, Postmodernism and the Poetics of Place, (London, Verso).

Lorente S. 1980 [1855]. Pensamientos sobre el Perú republicano del siglo XIX(Lima, Universidad Mayor de San Marcos).

Madrid, L. R. 2012. The Rise of Ethnic Politics in Latin America (Cambridge, Cambridge University Press).

Matos Mar, J. 1984. Desborde popular y crisis del estado: el nuevo rostro del Perú en la década de 1980 (Lima, Instituto de Estudios Peruanos).

Mauceri, P. 1995. 'State Reform, Coalitions, and the Neoliberal Autogolpe in Peru', in Latin American Research Review 30 (1) pp. 7-37.

Mendoza, Z. S. 2000. 'Performing decency: Ethnicity and race in Andean "Mestizo" ritual dance', in Music and the racial imagination, ed. P. Bohlman and R. Radano (Chicago, University of Chicago Press), pp. 231-270.

- 2008. Creating our own (Durham NC, Duke University Press).

Montero-Diaz, Fiorella. 2011. 'Danza de Tijeras. Through modernity and migration', in Musiké 5/6, III, 1, ed. I. Russell and F. Wilkins (London, SEMAR). 2016. 'Singing the war: reconfiguring white upper-class identity through fusion music in post-war Lima', in Ethnomusicology Forum, 25(2) pp. 191209

—. 2017. 'YouTubing the "other": Lima's upper classes and Andean imaginaries', in Music, Indigeneity, Digital Media, eds. T. Hilder, S.E Tan, H. Stobart (UK, University of Rochester Press), pp. 74-94.

Moore, Robin. 1997. Nationalizing Blackness: Afrocubanismo and Artistic Revolution in Havana, 1920-1940, (Pittsburgh, University of Pittsburgh Press). 
Version post- peer-review, pre editing; do not cite without permission of author

Ochoa Gautier, Ana María. 2003. Músicas locales en tiempos de globalización, (Bogota, Grupo Editorial Norma).

Olazo, J. 2002. Mixtura. Jazz con sabor peruano (Lima, Cocodrilo Verde ediciones).

Peirano, L. and A. Sanchez León. 1984. Risa y Cultura en la television peruana (Lima, DESCO).

Portocarrero, G. 1993. Racismo y mestizaje. (Lima, Ediciones Sur).

Quijano, A. 1980. Dominacion y Cultural / Lo Cholo y el conflicto Cultural en el Perú. (Lima, Mosca Azul).

Quispe, A. 2000. 'La “Cultura Chicha” en el Perú.' Paper presented in panel: Cultura Chicha en el Perú (Centro Federado de Letras de la Pontificia Universidad Católica del Perú) September 31. Accessed 16/05/12. http://interculturalidad.org/numero01/c/arti/c_chi_010404.htm

Ramos, A. 1994. 'The Hyperreal Indian', in Critique of Anthropology 14 (2): 153-171.

Ramos Garcia, L. 2003. 'Rock 'n' roll in Peru's popular quarters. Cultural Identity, hybridity and transculturation', in Musical Migrations. Transnationalism and Cultural Hybridity in Latin America. Volume I, ed F. R. Aparicio and C. F. Jaquez. Translated M.E. Cepeda ( New York, Palgrave Macmillan) pp. 199206.

Ritter, J. 2007. 'Terror in an Andean Key: Peasant Cosmopolitans Interpret 9/11', in Music in the Post-9/11 World, ed. J. Ritter and J. M. Daughtry (New York, Routledge) pp. 177-208. 2011. 'Chocolate, coconut, and Honey: Race, Music and the Politics of hybridity in the Ecuadorian Black Pacific', in Popular Music and Society, 34, (5): 571-592.

Riveros Vásquez, C. 2012. 'Formas de organización de las escenas musicales 
Version post- peer-review, pre editing; do not cite without permission of author

alternas en Lima. El caso de las bandas ska del bar Bernabé.' B.A diss., Pontificia Universidad Católica del Perú.

Romero, R. R. 2007. Andinos y Tropicales. La cumbia peruana en la ciudad global (Lima, Instituto de Etnomusicología - Pontificia Universidad Católica del Perú).

Rozas E. 2007. Fusión: banda sonora del Perú (Lima: Instituto de Etnomusicología, PUCP).

Slobin, Mark. 1993. Subcultural Sounds: Micromusics of the West, (Hanover, University Press of New England.

Stobart, H. 2006. Music and the Poetics of Production in the Bolivian Andes (Aldershot, Ashgate).

—. 2013. 'Sensational Sacrifices. Feasting the Senses in the Bolivian Andes', in Music, Sensation, and Sensuality, ed. L. Phyllis Austern (NY and London, Routledge) pp. 97-120.

Stokes, Martin, ed. 1994. Ethnicity, Identity and Music: the musical construction of place, (Oxford, Berg Publishers). 2004. 'Music and the Global Order', in Annual Review of Anthropology, 33 (2004): 47-72.

Taylor, Timothy. D. 1997. Global Pop: World Music, World Markets, (London, Routledge).

_. 2003. "A Riddle Wrapped in a Mystery: Transnational Music Sampling and Enigma's 'Return to Innocence', in Music and Technoculture, ed. R. T.A. Lysloff and L. C. Gay Jr, (Middletown Conn, Wesleyan University Press), pp. 64-92.

-2007. Beyond Exoticism, (Durham NC, Duke University Press). 
Version post-peer-review, pre editing; do not cite without permission of author

Tucker, J. 2013a. 'From the World of the Poor to the Beaches of Eisha. Chicha, Cumbia, and the Search for a Popular Subject in Peru', in Cumbia! Scenes of a Migrant Latin American Music Genre, ed. H. Fernández L’Hoeste and P. Vila (Durham, Duke University Press) pp. 138-167. 2013b. Gentleman Troubadours and Andean Pop Stars. Huayno Music,

Media Work, and Ethnic Imaginaries in Urban Peru (Chicago, University of Chicago Press).

Turino, T. 1989. 'The Coherence of Social Style and Musical Creation among the Aymara in Southern Peru', in Ethnomusicology 33 (1) (Illinois, University of Illinois Press) pp.1-30. 1993. Moving away from Silence: Music of the Peruvian Altiplano and the experiment of urban migration (Chicago, University of Chicago Press).

Valentin Escobar, Wilson. 2000. 'Marketing memory/Marketing Authenticity in Buena Vista Social Club Recordings'. Paper presented at XXII Latin American Studies Association International Congress LASA, Miami, March $16-18$.

Vianna, Hermano. 1999. The Mystery of Samba: Popular Music and National Identity in Brazil, (London, University of North Carolina Press).

Wade, Peter. 2000. Music, Race and Nation: Música tropical in Colombia, (Chicago and London, University if Chicago Press).

Weyland, Kurt. 2007. Bounded Rationality and Policy Diffusion: Social Sector Reform in Latin America, (Princeton, Princeton University Press).

\section{Interviews}

$\underline{\text { Academics }}$ 
Version post-peer-review, pre editing; do not cite without permission of author

Vásquez, Chalena, 17 August 2010 (conducted by the author), Lima.

\section{Performers}

Briones, Renato, 02 August 2010, 09 September 2010 and 02 March 2011 (conducted by the author), Lima.

González, Miki, 24 August 2006, 24 July 2008, 20 June 2011 (conducted by the author), Lima.

Manga, Dimitri, 21 July 2010 (conducted by the author), Lima.

Marcacuzco, Marino, 10 September 2010 (conducted by the author), Lima.

Pacheco, María Elena, 21 September 2010 (conducted by the author), Lima.

Pérez, Julio, 14 July 2010 (conducted by the author), Lima.

Solier, Magaly, 05 August 2010 (conducted by the author), Lima.

Members of the audience (all conducted by the author)

Mariafé, 28 years old - 2011, La Noche de Barranco, Lima.

María Fernanda, 26 years old -2011, La Noche de Barranco, Lima.

\section{Discography}

González, Miki. Puedes ser tú LP - Label: EMI. 1986

—. Tantas Veces LP - Label: CBS. 1987

—. Nunca les crei Cassettee - Label: DIN. 1989

—. Akundún CD - Label: Discos Hispanos del Perú. 1992

—. Hatun Exitokuna - Label: Discos Independientes. 1994

—. Akundún Etnohits CD - La República edition. Label: Mediasat América. 1997 
Version post- peer-review, pre editing; do not cite without permission of author

—. Etno Tronics Apu Sessions CD - Label: Apu Records. 2005

—. Inka Beats Apu Sessions CD [Previously Inkaterra 2004] - Label: Apu

Records. 2006

—. Iskay. Inka Beats CD - Label: Apu Records. 2006

—. Landó Por Bulerías CD - Label: Apu Records and Phantom Records. 2009

La Sarita. Más Poder CD - Label: IEMPSA. 1999 Danza La Raza CD - Label: IEMPSA. 2003 . Mamacha Simona CD - Label: PlayMusic\&Video. 2009 Identidad CD - Label: PlayMusic\&Video. 2012

Solier, Magaly .Warmi CD - Label: Phantom Records. 2009 